\title{
Pollution Studies on Soils from Crude Oil Producing Areas of Rivers State, Niger Delta Region, Nigeria
}

\author{
Chisom Onwuka, Augustine Nnaluo Eboatu, Vincent Ishmael Egbulefu Ajiwe, Ebele Joy Morah \\ Department of Pure and Industrial Chemistry, Nnamdi Azikiwe University, Awka, Nigeria \\ Email: chisompeters2@gmail.com
}

How to cite this paper: Onwuka, C., Eboatu, A.N., Ajiwe, V.I.E. and Morah, E.J. (2021) Pollution Studies on Soils from Crude Oil Producing Areas of Rivers State, Niger Delta Region, Nigeria. Open Access Library Journal, 8: e7583.

https://doi.org/10.4236/oalib.1107583

Received: May 25, 2021

Accepted: September 23, 2021

Published: September 26, 2021

Copyright $\odot 2021$ by author(s) and Open Access Library Inc.

This work is licensed under the Creative Commons Attribution International License (CC BY 4.0).

http://creativecommons.org/licenses/by/4.0/

\begin{abstract}
Soil pollution assessment was carried out in seven oil producing areas in Rivers State, and also in Nnamdi Azikiwe University, Awka which served as the control area. Five composite soil samples from five different locations were randomly collected in each local government area (L.G.A.) with oil deposits, at a depth of 1 metre using soil auger. The samples were air-dried, ground, sieved and analyzed for $\mathrm{pH}$, electrical conductivity, moisture content and heavy metals (cadmium, chromium, lead and nickel), using standard procedures. The data were subjected to statistical analysis using mean and bar graphs, and the results obtained were compared with those from the control area and DPR Standard. One way analysis of variance (ANOVA) was also done to establish the statistical difference between the study areas and the control area at 0.05 confidence level. The mean values of the parameters analyzed ranged as follows; $\mathrm{pH}: 4.25-6.48$, electrical conductivity: $2.45-10.60$ $\mu \mathrm{S} / \mathrm{cm}$, moisture: $0.60 \%-0.90 \%$, cadmium: $0.08-0.58 \mathrm{mg} / \mathrm{kg}$, chromium: $2.86-7.91 \mathrm{mg} / \mathrm{kg}$, lead: $0.22-9.79 \mathrm{mg} / \mathrm{kg}$ and nickel: $0.44-5.08 \mathrm{mg} / \mathrm{kg}$. The control values were; $\mathrm{pH}$ : 6.04, electrical conductivity: $92.00 \mu \mathrm{S} / \mathrm{cm}$, moisture: 0.80\%, cadmium: $0.09 \mathrm{mg} / \mathrm{kg}$, chromium: $8.72 \mathrm{mg} / \mathrm{kg}$, lead: $1.04 \mathrm{mg} / \mathrm{kg}$ and nickel: $0.89 \mathrm{mg} / \mathrm{kg}$. The results revealed that the $\mathrm{pH}$ levels of the soils were acidic and most of the values were within the DPR limit. Electrical conductivity and moisture contents of the soils were low and also below the control value and DPR standard. Heavy metal concentrations in the soils exceeded the control values but were below DPR limit. ANOVA results showed that there was a significant difference $(\mathrm{p}<0.05)$ between chromium concentration in the assessed soils and the control soil. The results obtained revealed that the examined areas in Rivers State were not yet adversely polluted in terms of oil exploration and exploitation activities. Therefore, periodic monitoring of the project areas is strongly recommended to prevent the buildup of these
\end{abstract}


contaminants beyond limits of maximum tolerance.

\section{Subject Areas}

Petrochemistry

\section{Keywords}

Soil Pollution, Oil Exploration, Heavy Metals, Rivers State

\section{Introduction}

Soil is an important natural resource for agriculture and industrial development of a nation. Its importance which cannot be over-emphasized can be seen in human, plant and animal survival as well as micro-biological organism. The significance for an in-depth study of the physical and chemical components of soils has been greatly highlighted by Ukpong [1] who discovered the inevitability of high soil quality for human survival [1]. Unfortunately, due to several anthropogenic and natural factors, the soil may become degraded and its productivity consequently lowered [2].

Oil exploration has continued to play a dominant role in the Nigerian economy, ranging from generation of foreign exchange to serving as a source of energy to run the nation's economy. The advent of oil exploration and exploitation activities resulted in increased pollution of the Niger Delta environment, through sabotage, accidental spillages, leaks from producing wells, storage tanks, gathering lines, pipelines, flow stations, refineries and industrial dump sites.

The environmental consequences of oil pollution on the inhabitants of Niger Delta Region are enormous. Oil production gives rise to the degradation of arable soils in the Niger Delta area, which create negative impact on the physical, chemical and biological properties of the soil [3]. The Niger Delta over the years has witnessed massive oil-based environmental degradation, soil fertility loss, agricultural decline, pollution of air and water, fisheries decline, destruction of wildlife and depletion of biodiversity [4]. According to a study carried out by a team of Nigerian and International environmental experts in 2006, the damage from oil operations is chronic and cumulative, and has acted synergistically with other source of environmental stress to result in a severely impaired coastal ecosystem, massively threatening the livelihood, health and basic survival of the region's impoverished residents [5].

Agriculture forms the most dominant economic activities in the Niger Delta Region, yet farmlands are lost to non-agricultural use annually at alarming rates due to oil spill. According to Onwurah [6] crude oil extraction and production have had adverse environmental effect on soils, forests and water bodies of the Niger Delta communities [6]. This has ultimately affected peasant agriculture in a variety of ways leading to drastic decline in farm products, intensive exploita- 
tion of other fertile lands, soil degradation, hunger, immigration, increased health issues and poverty in the region.

Soil pollution in Niger Delta Region is receiving worldwide attention yet information regarding this is very scanty. Apart from the data collected by some individuals and corporate bodies at scattered locations, there is no comprehensive database on the pollution status of these areas. Therefore, this study was conducted in order to examine the pollution levels of soils in the oil producing areas of Rivers State. Specific objectives of the study are to assess the physico-chemical properties and heavy metal contents of the soils, and also compare the values obtained with those obtained from the control area and with the acceptable limits of environmental agency [7]. This result will provide baseline information on the levels of damage that oil exploration has done to agricultural production for the farming communities.

\section{Materials and Methods}

\subsection{Study Area}

Rivers State is one of the thirty-six States of Nigeria located in South-South geopolitical zone of Nigeria. The State is divided into twenty-three local government areas. Its capital, Port Harcourt is economically significant as the leading supplier of wealth to the nations. Rivers State is famous for its vast deposits of crude oil and natural gas, generating over $60 \%$ of the country's output of crude oil [8]. It lies between latitude $4^{\circ} 44^{\prime} 59.06^{\prime \prime} \mathrm{N}$ and longitude $6^{\circ} 49^{\prime} 39.58^{\prime \prime} \mathrm{E}$. The total landmass is $11,077 \mathrm{~km}^{2}$, with a population of 7,043,800 [9]. It is bounded to the south by the Atlantic Ocean, to the north by Abia, Anambra and Imo, to the east by Akwa Ibom and to the West by Bayelsa and Delta States. The climate of the area is tropical, characterized by rainy and dry seasons. The wet season occurs between the months of March to October. The only dry months are November to February, having little or no effect. The rainfall is high which decreases from about $4,700 \mathrm{~mm}$ on the coast to about $1,700 \mathrm{~mm}$ in the extreme north. The mean monthly temperature is between $25^{\circ} \mathrm{C}$ to $28^{\circ} \mathrm{C}$, while the mean annual temperature is $26^{\circ} \mathrm{C}$. Relative humidity is high, above $60 \%$ and fluctuates between $90 \%$ and $100 \%$ for most of the year. Fishing and farming are the main occupation of the region. It is one of the leading States in the production of yam, cassava, maize, rice, beans, and major cash crops such as oil palm, rubber, coconut, raffia palm and jute. The State also provides valuable sea foods such as crabs, oysters, shrimps, snail and many others.

Figure 1 shows the map of Rivers State and the study areas, all coordinates are listed in Table 1.

\subsection{Sample Selection}

Seven oil producing local government areas in Rivers State were selected for this study as shown in Figure 1, which include Ahoada West, Eleme, Emohua, Etche, Ikwere, Ogba-Egbema-Ndoni, and Oyigbo. Five (5) sites from each local 


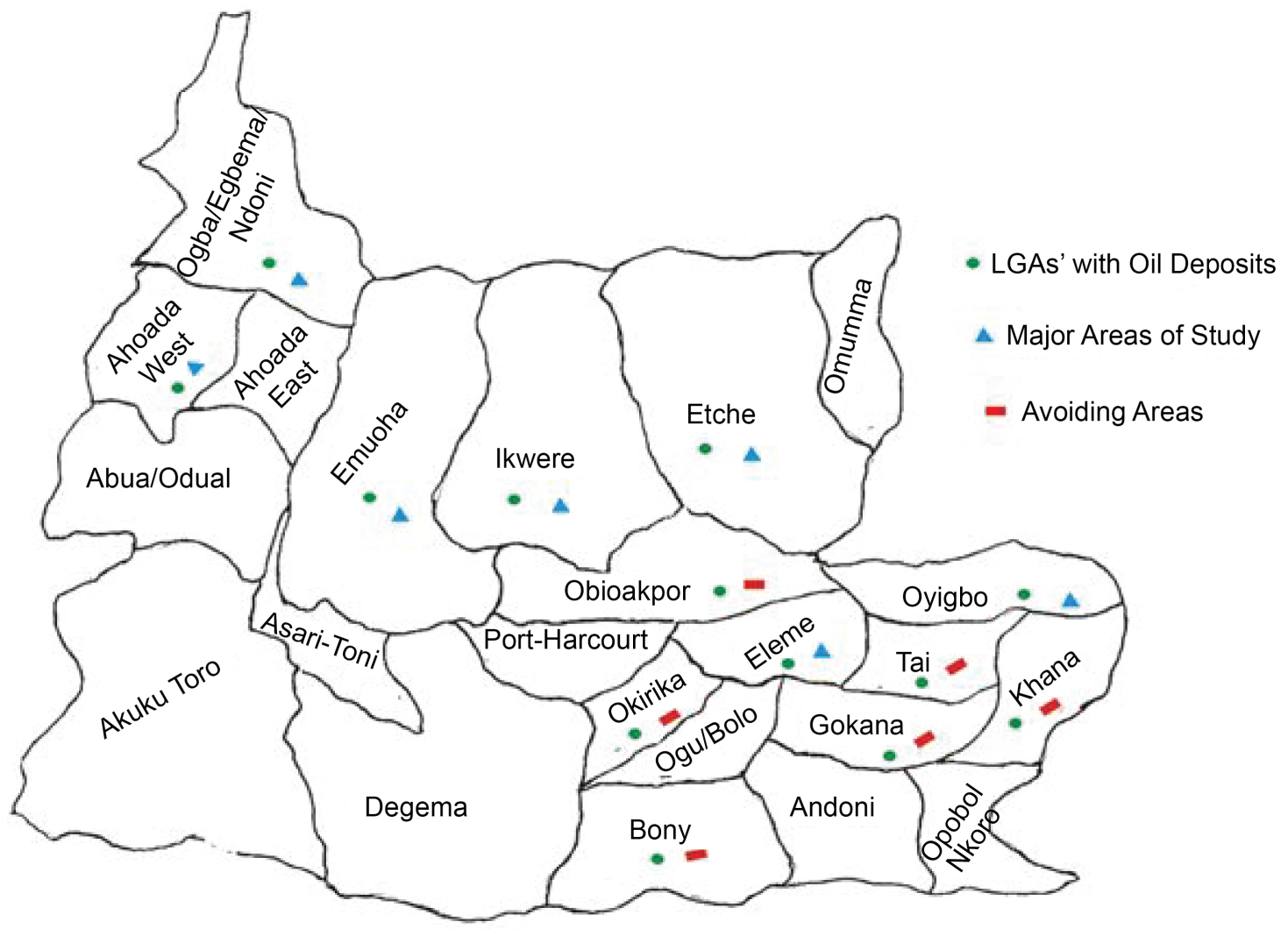

$\overline{070140 \quad 280420 \quad 560}$ Kilometers

Figure 1. Map of Rivers showing the study areas.

Table 1. G.P.S. co-ordinates of the different sampling points in Rivers State.

\begin{tabular}{|c|c|c|c|}
\hline L.G.A. & Sampling Points & Latitude & Longitude \\
\hline \multirow[t]{5}{*}{ Ahoada West } & 1 & $5^{\circ} 3^{\prime} 14^{\prime \prime N}$ & $6^{\circ} 37^{\prime} 59^{\prime \prime} \mathrm{E}$ \\
\hline & 2 & $5^{\circ} 4^{\prime} 17^{\prime \prime N}$ & $6^{\circ} 40^{\prime} 32^{\prime \prime} \mathrm{E}$ \\
\hline & 3 & $5^{\circ} 3^{\prime} 56^{\prime \prime N}$ & $6^{\circ} 40^{\prime} 15^{\prime \prime} \mathrm{E}$ \\
\hline & 4 & $5^{\circ} 5^{\prime} 44^{\prime \prime} \mathrm{N}$ & $6^{\circ} 40^{\prime} 28^{\prime \prime} \mathrm{E}$ \\
\hline & 5 & $5^{\circ} 5^{\prime} 25^{\prime \prime} \mathrm{N}$ & $6^{\circ} 38^{\prime} 20^{\prime \prime} \mathrm{E}$ \\
\hline \multirow[t]{5}{*}{ Eleme } & 6 & $5^{\circ} 5^{\prime} 9 " \mathrm{~N}$ & $6^{\circ} 35^{\prime} 13^{\prime \prime} \mathrm{E}$ \\
\hline & 7 & $5^{\circ} 4^{\prime} 22^{\prime \prime} \mathrm{N}$ & $6^{\circ} 37^{\prime} 0^{\prime \prime} \mathrm{E}$ \\
\hline & 8 & $5^{\circ} 5^{\prime} 53^{\prime \prime N}$ & $6^{\circ} 37^{\prime} 8^{\prime \prime} \mathrm{E}$ \\
\hline & 9 & $5^{\circ} 4^{\prime} 47^{\prime \prime} \mathrm{N}$ & $6^{\circ} 37^{\prime} 24^{\prime \prime} \mathrm{E}$ \\
\hline & 10 & $5^{\circ} 4^{\prime} 31^{\prime \prime} \mathrm{N}$ & $6^{\circ} 38^{\prime} 45^{\prime \prime} \mathrm{E}$ \\
\hline \multirow[t]{5}{*}{ Emohua } & 11 & $4^{\circ} 56^{\prime} 24^{\prime \prime} \mathrm{N}$ & $6^{\circ} 52^{\prime} 11 " \mathrm{E}$ \\
\hline & 12 & $4^{\circ} 56^{\prime} 5^{\prime \prime N}$ & $6^{\circ} 51^{\prime} 41^{\prime \prime} \mathrm{E}$ \\
\hline & 13 & $4^{\circ} 53^{\prime} 30^{\prime \prime} \mathrm{N}$ & $6^{\circ} 53^{\prime} 60^{\prime \prime} \mathrm{E}$ \\
\hline & 14 & $4^{\circ} 54^{\prime} 18^{\prime \prime} \mathrm{N}$ & $6^{\circ} 51^{\prime} 55^{\prime \prime} \mathrm{E}$ \\
\hline & 15 & $4^{\circ} 54^{\prime} 39^{\prime \prime} \mathrm{N}$ & $6^{\circ} 51^{\prime} 29^{\prime \prime} \mathrm{E}$ \\
\hline
\end{tabular}




\section{Continued}

\begin{tabular}{|c|c|c|c|}
\hline \multirow[t]{5}{*}{ Etche } & 16 & $4^{\circ} 60^{\prime} 50^{\prime \prime} \mathrm{N}$ & $7^{\circ} 3^{\prime} 52^{\prime \prime} \mathrm{E}$ \\
\hline & 17 & $4^{\circ} 58^{\prime} 12^{\prime \prime N}$ & $7^{\circ} 3^{\prime} 10^{\prime \prime} \mathrm{E}$ \\
\hline & 18 & $4^{\circ} 58^{\prime} 46^{\prime \prime} \mathrm{N}$ & $7^{\circ} 5^{\prime} 23^{\prime \prime} \mathrm{E}$ \\
\hline & 19 & $4^{\circ} 58^{\prime} 35^{\prime \prime} \mathrm{N}$ & $7^{\circ} 3^{\prime} 37^{\prime \prime} \mathrm{E}$ \\
\hline & 20 & $4^{\circ} 59^{\prime} 2 " \mathrm{~N}$ & $7^{\circ} 7^{\prime} 16^{\prime \prime} \mathrm{E}$ \\
\hline \multirow[t]{5}{*}{ Ikwere } & 21 & $5^{\circ} 4^{\prime} 7^{\prime \prime} \mathrm{N}$ & $6^{\circ} 57^{\prime} 4^{\prime \prime} \mathrm{E}$ \\
\hline & 22 & $5^{\circ} 11^{\prime} 60^{\prime \prime N}$ & $6^{\circ} 53^{\prime} 40^{\prime \prime} \mathrm{E}$ \\
\hline & 23 & $5^{\circ} 3^{\prime} 51^{\prime \prime N}$ & $6^{\circ} 55^{\prime} 47^{\prime \prime} \mathrm{E}$ \\
\hline & 24 & $5^{\circ} 4^{\prime} 15^{\prime \prime N}$ & $6^{\circ} 55^{\prime} 26^{\prime \prime} \mathrm{E}$ \\
\hline & 25 & $5^{\circ} 4^{\prime} 33^{\prime \prime} \mathrm{N}$ & $6^{\circ} 56^{\prime} 54^{\prime \prime} \mathrm{E}$ \\
\hline \multirow[t]{5}{*}{ Ogba-Egbema } & 26 & $5^{\circ} 23^{\prime} 37^{\prime \prime} \mathrm{N}$ & $6^{\circ} 39^{\prime} 42^{\prime \prime} \mathrm{E}$ \\
\hline & 27 & $5^{\circ} 22^{\prime} 10^{\prime \prime} \mathrm{N}$ & $6^{\circ} 37^{\prime} 18^{\prime \prime} \mathrm{E}$ \\
\hline & 28 & $5^{\circ} 20^{\prime} 58^{\prime \prime} \mathrm{N}$ & $6^{\circ} 37^{\prime} 31^{\prime \prime E}$ \\
\hline & 29 & $5^{\circ} 20^{\prime} 8^{\prime \prime N}$ & $6^{\circ} 37^{\prime} 24^{\prime \prime} \mathrm{E}$ \\
\hline & 30 & $5^{\circ} 20^{\prime} 26^{\prime \prime} \mathrm{N}$ & $6^{\circ} 39^{\prime} 0^{\prime \prime} \mathrm{E}$ \\
\hline \multirow[t]{5}{*}{ Oyigbo } & 31 & $4^{\circ} 50^{\prime} 3 " \mathrm{~N}$ & $7^{\circ} 7^{\prime} 56^{\prime \prime} \mathrm{E}$ \\
\hline & 32 & $4^{\circ} 52^{\prime} 34^{\prime \prime N}$ & $7^{\circ} 8^{\prime} 19^{\prime \prime} \mathrm{E}$ \\
\hline & 33 & $4^{\circ} 52^{\prime} 13^{\prime \prime N}$ & $7^{\circ} 6^{\prime} 44^{\prime \prime} \mathrm{E}$ \\
\hline & 34 & $4^{\circ} 53^{\prime} 23^{\prime \prime} \mathrm{N}$ & $7^{\circ} 8^{\prime} 30^{\prime \prime} \mathrm{E}$ \\
\hline & 35 & $4^{\circ} 53^{\prime} 57^{\prime \prime} \mathrm{N}$ & $7^{\circ} 8^{\prime} 6^{\prime \prime} \mathrm{E}$ \\
\hline
\end{tabular}

government area were chosen for sampling. The control sample was selected from Nnamdi Azikiwe university (NAU) Awka, Anambra state, which is a none oil producing area.

\subsection{Sample Collection}

Five composite soil samples (20 samples) from five different locations were randomly collected in each local government area with oil deposits, avoiding areas such as areas under construction, areas that are shut down, areas whose oil wells have dried up and riverine areas. For each collecting site, four soil samples were taken and combined together to form a representative sample of that location. The control samples were randomly collected from Nnamdi Azikiwe University premises in the same manner, for comparison with the oil producing areas. All soil samples were collected at a depth of 1 meter, using hand-driven soil auger. The collected soil samples were put in labeled plastic cans and conveyed to the laboratory for further processing. The sample collection was carried out biweekly for a period of six months.

\subsection{Sample Preparations}

The collected soil samples were air-dried to a constant weight for three days, 
ground with porcelain mortar and pestle, and sieved through a $500 \mu \mathrm{m}$ stainless sieve. The soil samples (500 g) were securely packaged in clean, dry, closed plastic cans, individually labelled and taken to the laboratory for analysis of various parameters.

\subsection{Sample Analysis}

The soil analyses were carried out in the laboratory following appropriate specific standard procedures for each parameter. The parameters analyzed include:

\subsubsection{Determination of $\mathrm{pH}$}

The $\mathrm{pH}$ of the samples was measured using the $\mathrm{pH}$ meter (HI 8424 HANNA Romania) at 1:2 soil/water ratio. The soil sample (20.0 g) was weighed into 250 $\mathrm{mL}$ beaker, using Sartorius weighing balance (AE200 METTLER, Switzerland). $40 \mathrm{~mL}$ of deionized water was added to it and the mixture was stirred thoroughly with a glass rod for proper mixing. The mixture was allowed to settle for $45 \mathrm{mi}$ nutes. The reading was obtained by immersing the $\mathrm{pH}$ probe into the settled mixture. The $\mathrm{pH}$ meter was calibrated using standard buffer solution at $\mathrm{pH} 4$ and $\mathrm{pH} 7$ before taking measurements

\subsubsection{Determination of Electrical Conductivity}

The conductivity of the samples was measured using a conductivity meter (HI 98303 HANNA, Romania) at 1:2 soil/water ratio. The soil sample (20.0 g) was weighed into $250 \mathrm{~mL}$ beaker, using Sartorius weighing balance (AE200 METTLER, Switzerland). $40 \mathrm{~mL}$ of deionized water was added. The mixture was thoroughly stirred with a glass rod and was allowed to settle for 45 minutes. The reading was obtained by immersing the conductivity probe into the settled mixture.

\subsubsection{Determination of Moisture Content}

The moisture content was determined gravimetrically. The soil sample (10.0 g) was weighed into a ceramic crucible of known weight. This was placed in the drying oven set at $105^{\circ} \mathrm{C}$ and was allowed to dry for three hours until constant weight was obtained. The sample was allowed to cool in a desiccator for $30 \mathrm{mi}$ nutes. The sample was reweighed and the difference in weight (expelled moisture) was calculated. The percentage moisture was deduced as follows;

$$
\% \text { moisture }=\frac{A-B}{A} X \frac{100}{1}
$$

where

$$
\begin{aligned}
& A=\text { Weight of the sample before drying; } \\
& B=\text { Weight of the Sample after drying. }
\end{aligned}
$$

\subsubsection{Digestion of Samples for Heavy Metals Analysis}

The samples were digested using aqua regia, which is 3:1 mixture of hydrochloric acid and trioxonitrate (V) acid. Soil sample (5.0 g) was weighed into a digestion flask. $15 \mathrm{~mL}$ of hydrochloric acid, $5 \mathrm{~mL}$ of trioxonitrate (V) acid and $30 \mathrm{~mL}$ of deionized water, were added to the weighed sample. The total volume was 
heated on a heating mantle in the fume cupboard for two hours until the volume reduced to about $15 \mathrm{~mL}$. The digest was then cooled and about $30 \mathrm{~mL}$ of deionized water was added. This was filtered through a 42 Whatman filter paper into $50 \mathrm{~mL}$ volumetric flask and was made up to the mark with deionized water. The filtrates of the digested samples were then analyzed for heavy metals.

\subsubsection{Determination of Heavy Metals}

The concentrations of the heavy metals (cadmium, chromium, lead and nickel) were determined using flame atomic absorption spectrophotometer (A6600 GBC AVANTA PM, Australia) at wavelengths of $228.8 \mathrm{~nm}, 357.9 \mathrm{~nm}, 217.0 \mathrm{~nm}$ and $232.0 \mathrm{~nm}$ respectively. Standards of cadmium, chromium, lead and nickel solutions were made from each of the heavy metals stock solutions. The standard samples of the metals to be analyzed were injected into the AAS instrument to obtain their absorbance from which the calibration graphs of each metal were plotted using measured absorbance and the corresponding concentration. The filtrates of the digested samples were then injected into the AAS instrument and the absorbance measured was used to determine the concentrations of the metals present, from the calibration curves. The result was given in $\mathrm{mg} / \mathrm{kg}$.

\subsubsection{Data Analysis}

The data generated were analyzed using descriptive statistics. Tables, bar charts, mean and standard deviation were computed to show the concentration levels of contaminants in the soil samples. One way analysis of variance (ANOVA) was used to determine the statistically significant difference $(\mathrm{p}<0.05)$ between the study areas and the control area, using computer aided SPSS Statistical Program.

\section{Results and Discussions}

The $\mathrm{pH}$ analysis results of soils of the surveyed local governments in Rivers State are shown in Table 2 and Figure 2.

Results obtained (Table 2) depicted that the mean $\mathrm{pH}$ levels of examined soils from Rivers State ranged from 4.25 to 6.48 . The highest $\mathrm{pH}$ value was observed in Emohua (6.48), probably as a result of the presence of residual hydrocarbon spill which must have posed a major resistance to the leaching of basic salts that are responsible for the raising of the $\mathrm{pH}$. The presence of hydrogen sulphide which is one of the end products of biodegradation of petroleum, may account for the least value recorded in Oyibo (4.25). The average $\mathrm{pH}$ levels of all the sites assessed in Rivers (4.25 - 5.98) were below the control site (6.04), with the exception of Emohua (6.48) which exceeded the control (Table 2 and Figure 2). Table 2, Table 3 and Figure 2, also revealed that the mean $\mathrm{pH}$ values of Ahoada West (5.02), Ogba Egbema (4.78) and Oyibo (4.25) were lower than department of petroleum resources (DPR) limit (5.50 - 6.50), while Eleme (5.98), Emohua (6.48), Etche (5.50) and Ikwere (5.68) were within the limit. This study revealed that oil production activities had some impact on the soil $\mathrm{pH}$ of some study areas of 


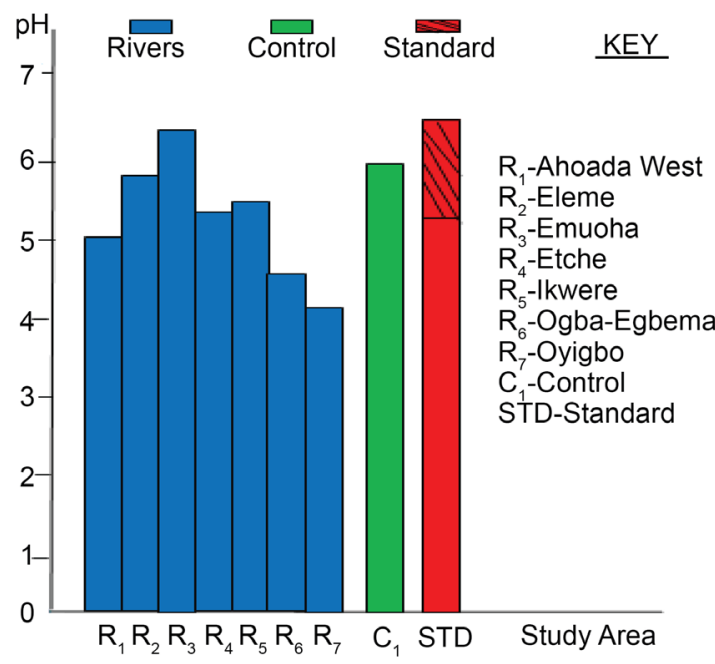

Figure 2. Graphical representation of the effect of oil exploration on soil $\mathrm{pH}$ of Rivers State.

Table 2. Summary (averages) of soil analysis.

\begin{tabular}{cccccccc}
\hline $\begin{array}{c}\text { Local Govt. } \\
\text { Area }\end{array}$ & $\mathrm{pH}$ & $\begin{array}{c}\mathrm{EC} \\
(\mu \mathrm{S} / \mathrm{cm})\end{array}$ & $\begin{array}{c}\text { Moisture } \\
(\%)\end{array}$ & $\begin{array}{c}\mathrm{Cd} \\
(\mathrm{mg} / \mathrm{kg})\end{array}$ & $\begin{array}{c}\mathrm{Cr} \\
(\mathrm{mg} / \mathrm{kg})\end{array}$ & $\begin{array}{c}\mathrm{Pb} \\
(\mathrm{mg} / \mathrm{kg})\end{array}$ & $\begin{array}{c}\mathrm{Ni} \\
(\mathrm{mg} / \mathrm{kg})\end{array}$ \\
\hline Ahoada West & $5.02 \pm$ & $3.61 \pm$ & $0.80 \pm$ & $0.08 \pm$ & $6.71 \pm$ & $2.87 \pm$ & $5.08 \pm$ \\
& 1.92 & 1.51 & 0.57 & 0.05 & 1.23 & 1.42 & 1.42 \\
Eleme & $5.98 \pm$ & $2.85 \pm$ & $0.90 \pm$ & $0.58 \pm$ & $4.59 \pm$ & $2.73 \pm$ & $0.44 \pm$ \\
& 1.63 & 1.39 & 0.50 & 0.39 & 0.48 & 1.83 & 0.62 \\
Emohua & $6.48 \pm$ & $5.55 \pm$ & $0.70 \pm$ & $0.11 \pm$ & $5.37 \pm$ & $1.83 \pm$ & $1.20 \pm$ \\
& 2.74 & 3.07 & 0.22 & 0.10 & 0.87 & 0.94 & 0.20 \\
Etche & $5.50 \pm$ & $10.60 \pm$ & $0.90 \pm$ & $0.12 \pm$ & $5.12 \pm$ & $1.58 \pm$ & $1.39 \pm$ \\
& 1.01 & 2.16 & 0.39 & 0.07 & 1.63 & 0.57 & 0.56 \\
Ikwere & $5.68 \pm$ & $2.45 \pm$ & $0.70 \pm$ & $0.08 \pm$ & $3.01 \pm$ & $0.22 \pm$ & $1.11 \pm$ \\
& 1.69 & 0.99 & 0.43 & 0.13 & 1.17 & 0.12 & 0.61 \\
Ogba-Egbema & $4.78 \pm$ & $2.81 \pm$ & $0.60 \pm$ & $0.08 \pm$ & $2.86 \pm$ & $3.56 \pm$ & $0.92 \pm$ \\
& 1.79 & 1.89 & 0.42 & 0.05 & 1.12 & 1.09 & 0.49 \\
Oyigbo & $4.25 \pm$ & $7.30 \pm$ & $0.70 \pm$ & $0.16 \pm$ & $7.91 \pm$ & $9.79 \pm$ & $2.01 \pm$ \\
& 1.78 & 2.50 & 0.29 & 0.16 & 1.44 & 3.63 & 0.64 \\
Unizik & $6.04 \pm$ & $92.00 \pm$ & $0.80 \pm$ & $0.09 \pm$ & $8.72 \pm$ & $1.04 \pm$ & $0.89 \pm$ \\
& 1.84 & 20.00 & 0.50 & 0.08 & 2.34 & 0.85 & 0.41 \\
\hline
\end{tabular}

Table 3. Ranges, State Means and P-values for the various Parameters.

\begin{tabular}{cccccc}
\hline & \multicolumn{2}{c}{ State } & \multicolumn{3}{c}{ Standard } \\
\hline Parameters & Range & Mean \pm SD & Control & $\left(\mathrm{DPR}^{17}\right)$ & P-value \\
\hline $\mathrm{pH}$ & $4.25-6.48$ & $5.38 \pm 1.83$ & $6.04 \pm 1.84$ & $5.50-6.50$ & 0.413 \\
Electrical Conductivity $(\mu \mathrm{S} / \mathrm{cm})$ & $2.45-10.60$ & $5.02 \pm 3.39$ & $92.00 \pm 20.00$ & $300-5000$ & 0.225 \\
Moisture Content (\%) & $0.60-0.90$ & $0.76 \pm 0.39$ & $0.80 \pm 0.50$ & $13-26$ & 0.834 \\
Cadmium (mg/kg) & $0.08-0.58$ & $0.17 \pm 0.23$ & $0.09 \pm 0.08$ & 0.8 & 0.517 \\
Chromium $(\mathrm{mg} / \mathrm{kg})$ & $2.86-7.91$ & $5.08 \pm 2.03$ & $8.72 \pm 2.34$ & 100 & 0.002 \\
Lead $(\mathrm{mg} / \mathrm{kg})$ & $0.22-9.79$ & $3.23 \pm 3.30$ & $1.04 \pm 0.85$ & 85 & 0.538 \\
Nickel $(\mathrm{mg} / \mathrm{kg})$ & $0.44-5.08$ & $1.74 \pm 1.60$ & $0.89 \pm 0.40$ & 35 & 0.206 \\
\hline
\end{tabular}


Rivers State, mainly Ahoada west, Ogba-Egbema and Oyibo, which can adversely affect soil fertility and crop production in these areas.

The electrical conductivity analysis results of soils of the assessed local governments in Rivers State are displayed in Table 2 and Figure 3.

The mean soil electrical conductivities of the investigated areas in Rivers increased from $2.45 \mu \mathrm{S} / \mathrm{cm}$ to $10.60 \mu \mathrm{S} / \mathrm{cm}$ (Table 2 ). The maximum value was determined in Etche $(10.60 \mu \mathrm{S} / \mathrm{cm})$, may be as results of the accumulation of salts due to the frequent flooding of the area with saline water, that characterizes the area. The various oil extracting and processing operations in Ikwere, may result to regular crude oil spillages, which may account for the observed low value in this area, since organic compound such as crude oil cannot conduct electric current because it does not contain free ions. The mean electrical conductivity values of the assessed areas in Rivers $(2.45-10.60 \mu \mathrm{S} / \mathrm{cm})$ were considerably lower than the background soil $(92.00 \mu \mathrm{S} / \mathrm{cm})$ and DPR stipulated limit $(300-5,000$ $\mu \mathrm{S} / \mathrm{cm}$ ) as indicated in Table 2, Table 3 and Figure 3 . The results obtained showed that the study areas of Rivers State were highly depleted of important nutrients that are necessary for plant growth, and therefore cannot favour high crop yield.

The results of moisture content analysis of soils of the investigated local government areas in Rivers State are indicated in Table 2 and Figure 4.

Table 2 indicated that the analyzed soils from Rivers varied from $0.6 \%$ to $0.9 \%$. The highest value was recorded in Eleme and Etche $(0.90 \%)$, which implies that these areas retained more water than other areas, probably as a result of metabolic processes following oil spill, precipitation and organic matter content of the soils. The least value was recorded in Ogba-Egbema $(0.60 \%)$, which could

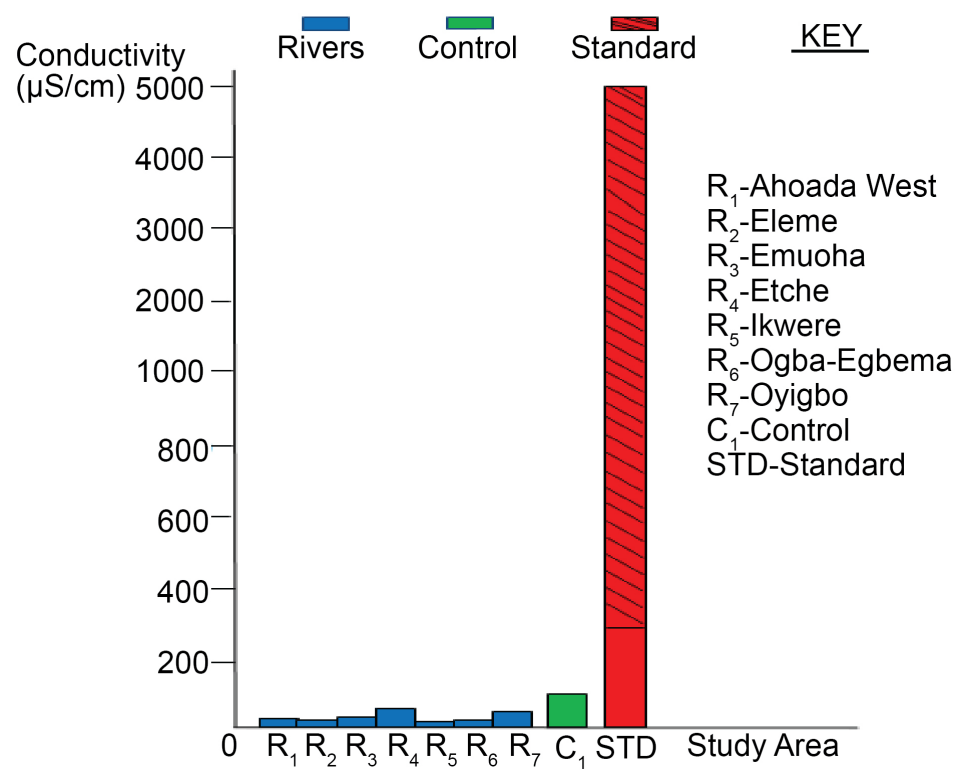

Figure 3. Graphical representation of the effects of oil exploration on soilelectrical conductivity of Rivers State. 


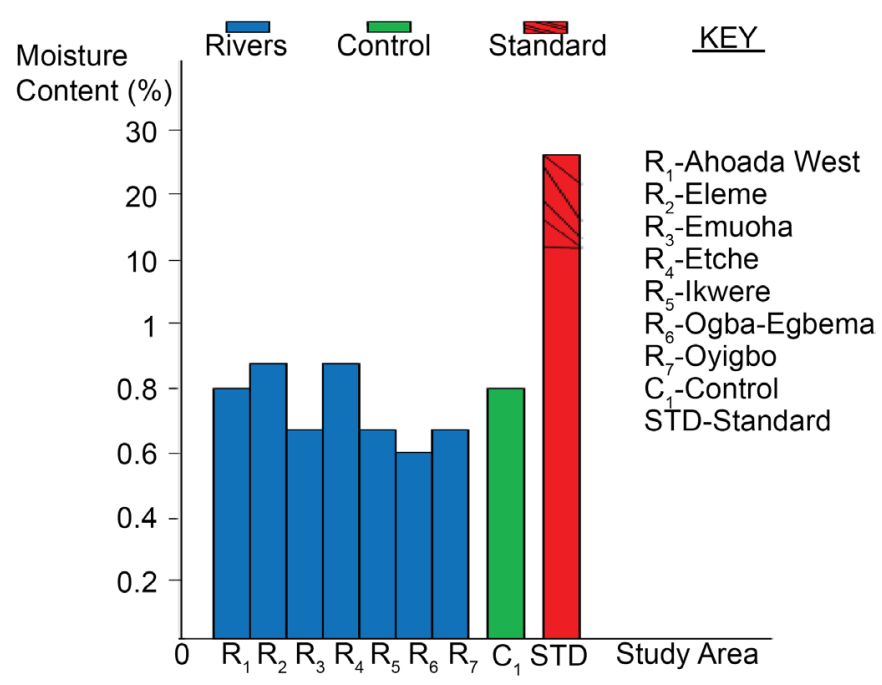

Figure 4. Graphical representation of the effect of oil exploration on soil moisture content of Rivers State.

be as a result of oil aerations and high rate of evaporation due to gas flaring, thereby increasing the moisture deficit in the soil. The resultant effect could lead to delayed seed germination, reduction in plant growth and in the population of hydrocarbons degrading microbes. Table 2 and Figure 4, revealed that the average soil moisture content of Eleme and Etche $(0.90 \%)$ were higher than the control value $(0.80 \%)$, but the Ahaoda West $(0.80 \%)$ had the same value with the control (0.80\%), while Emohua, Ikwere and Oyibo (0.70\%), and Ogba-Egbema $(0.60 \%)$ were lower than the control. All the examined soils from Rivers $(0.60 \%$ $0.90 \%$ ) were substantially below DPR standard of $13 \%-26 \%$ (Table 2, Table 3 and Figure 4). These results indicate that the assessed sites in Rivers State may have low soil fertility and poor agricultural output.

The results of cadmium analysis in the soils of the examined local government areas in Rivers State are shown in Table 2 and Figure 5.

In Rivers, the mean concentration of cadmium ranged from $0.08 \mathrm{mg} / \mathrm{kg}$ to $0.58 \mathrm{mg} / \mathrm{kg}$ as described in Table 2. The highest value was found in Eleme $(0.58$ $\mathrm{mg} / \mathrm{kg}$ ) probably as a result of the effluents from Eleme petroleum refinery, industrial wastes from Eleme petrochemical industry, oil spillage and the burning of crude oil in oil wells and flow stations which release significant amount of cadmium into the environment. The lowest value was seen in Ahoada West, Ikwere and Ogba-Egbema $(0.08 \mathrm{mg} / \mathrm{kg})$. These areas may likely have similar soil characteristics therefore; the materials from which the soils were formed may have influenced the distribution of cadmium in these areas. It was explained (Table 2 and Figure 5) that the mean cadmium concentrations of Eleme (0.58 $\mathrm{mg} / \mathrm{kg})$, Emohua $(0.11 \mathrm{mg} / \mathrm{kg})$, Etche $(0.12 \mathrm{mg} / \mathrm{kg})$, and Oyibo $(0.16 \mathrm{mg} / \mathrm{kg})$ were above the control site $(0.09 \mathrm{mg} / \mathrm{kg})$, while Ahoada west, Ikwere and Ogba-Egbema $(0.08 \mathrm{mg} / \mathrm{kg})$ were below the control. The average concentrations of cadmium in all the sites surveyed in Rivers $(0.08-0.58 \mathrm{mg} / \mathrm{kg})$ were comparatively below the DPR target value $(0.80 \mathrm{mg} / \mathrm{kg})$, as illustrated in Table 2, Table 3 


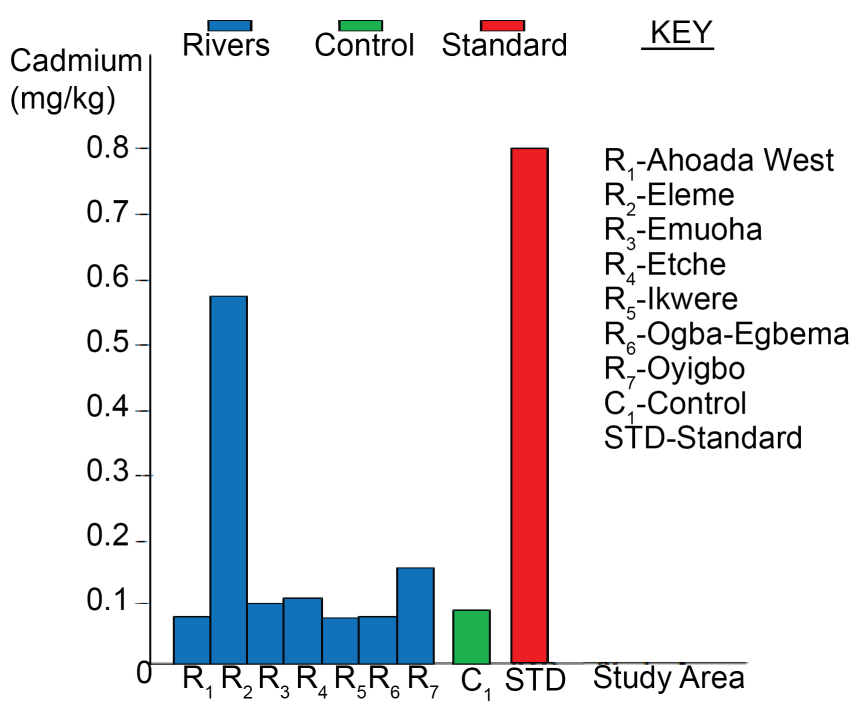

Figure 5. Graphical representation of the concentrations of cadmium in the assessed soils of Rivers State.

and Figure 5. Thus, the cadmium levels recorded do not have any hazardous effect in the assessed areas in Rivers State.

The results of the analysis of chromium in the soils of the assessed local government areas in Rivers State are depicted in Table 2 and Figure 6.

Table 2 revealed that the average levels of chromium in the analyzed soils from Rivers varied from $2.86 \mathrm{mg} / \mathrm{kg}$ to $7.91 \mathrm{mg} / \mathrm{kg}$. The highest concentration was detected in Oyibo $(7.91 \mathrm{mg} / \mathrm{kg})$, may be due to different oil-related activities going on at the NNPC gas plant and other flow stations within the area, which constantly release crude oil with high chromium content that found its way into the surrounding soils. Osibanjo et al. (1983) reported that Nigerian crude oil is rich in heavy metals, probably due to the fact that they are present in organometallic compounds that migrate with hydrocarbon, thereby acting as effective catalysts for the formation of hydrocarbon [10]. The lowest value obtained in Ogba-Egbema $(2.86 \mathrm{mg} / \mathrm{kg})$ is in agreement with the fact that the soil is very acidic (4.78) in nature (Table 2), and such soil $\mathrm{pH}$ gives the soil low buffering capacity and a low capacity for the retention of heavy metals [11]. In Table 2, Table 3 and Figure 6, all the studied sites in Rivers $(2.86-7.91 \mathrm{mg} / \mathrm{kg}$ ) had mean chromium concentrations lower than that of the background site $(8.72 \mathrm{mg} / \mathrm{kg})$ and DPR limit $(100 \mathrm{mg} / \mathrm{kg})$. These results revealed that the levels of chromium found in the analyzed soils from Rivers, could not be considered hazardous.

The results of the analysis of lead in the soils of the studied local government areas in Rivers State are described in Table 2 and Figure 7.

In Table 2, the mean levels of lead in the soil samples from Rivers were in the range of $0.22 \mathrm{mg} / \mathrm{kg}$ to $9.79 \mathrm{mg} / \mathrm{kg}$. The maximum value discovered in Oyibo $(9.79 \mathrm{mg} / \mathrm{kg})$, may be attributed to incessant crude oil spillage, as well as lead discharge from car batteries, gasoline, engine oil, lubricating oil and grease, and spilled leaded fuels which were carried by runoff from the oil companies 


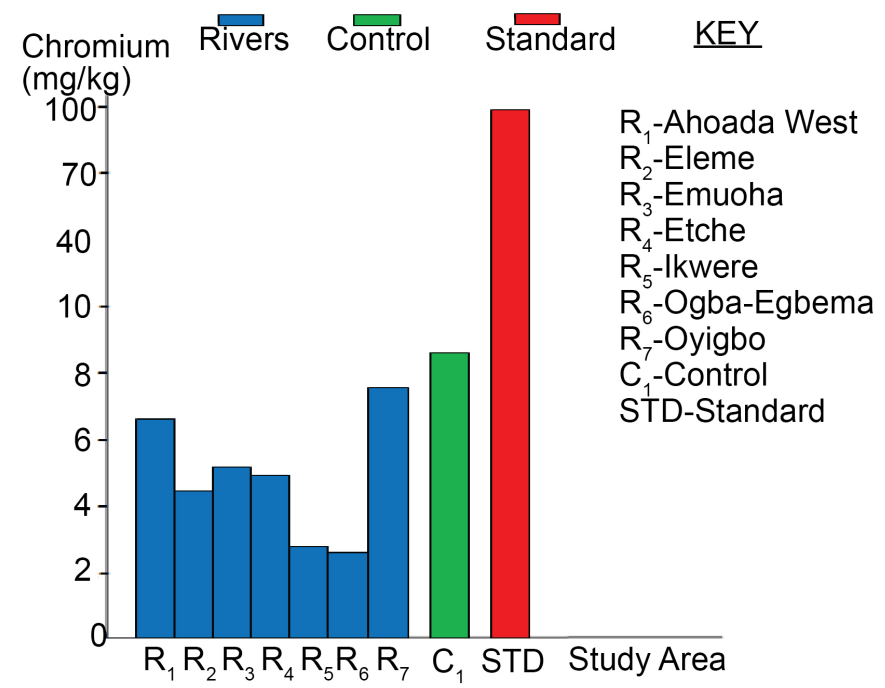

Figure 6. Graphical representation of the concentrations of chromium in the examined soils of Rivers State.

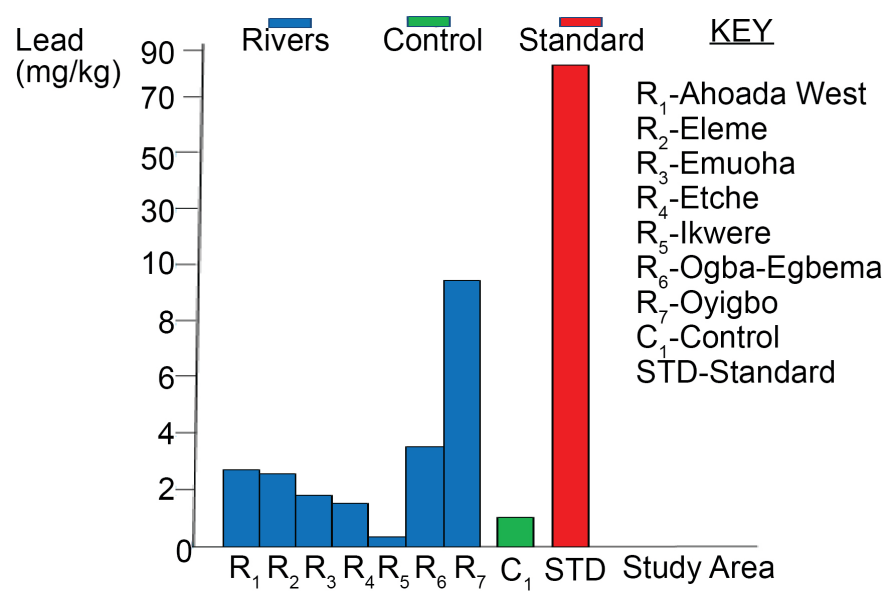

Figure 7. Graphical representation of the Concentrations of lead in the soils of Rivers State.

mechanic workshop into the surroundings soils; while the cleansing action of rainfall may be responsible for the minimum value found in Ikwere $(0.22 \mathrm{mg} / \mathrm{kg})$. From the data obtained (Table 2 and Figure 7), the mean values of lead determined in the test soils from Rivers $(1.58-9.79 \mathrm{mg} / \mathrm{kg}$ ) were all higher than the background soil $(1.04 \mathrm{mg} / \mathrm{kg})$, except that from Ikwere $(0.22 \mathrm{mg} / \mathrm{kg})$ which was unexpectedly lower than the control. Table 2, Table 3 and Figure 7, also depicted that the average values of lead for the areas studied in Rivers (0.22 - 9.79 $\mathrm{mg} / \mathrm{kg}$ ) were substantially lower than DPR critical value $(85 \mathrm{mg} / \mathrm{kg})$. From all indications, the levels of lead found in the studied locations in Rivers State, will not exert adverse effects on soil properties, plant community, soil dwelling organisms or humans.

The results of the analysis of nickel in the soils of the inspected local government areas in Rivers State are outlined in Table 2 and Figure 8. 


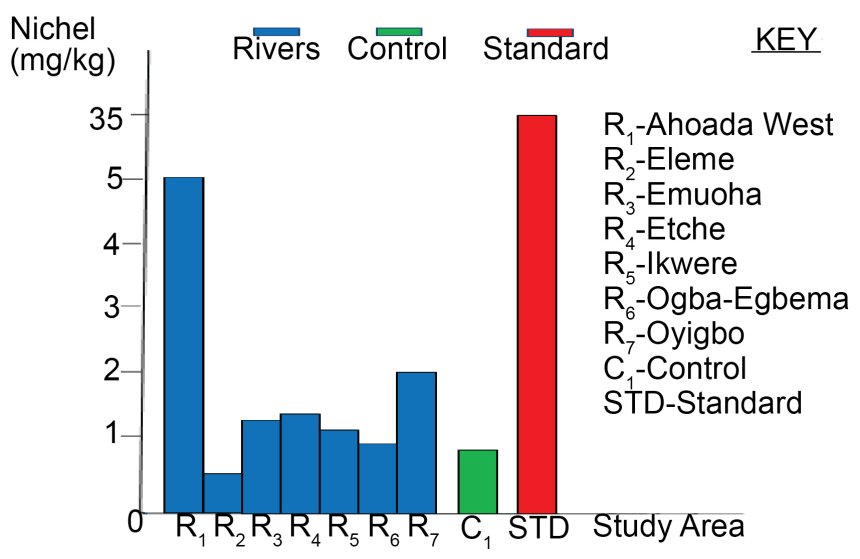

Figure 8. Graphical representation of the concentrations of nickel in the soils of Rivers State.

The average levels of nickel observed in the studied locations in Rivers (Table 2), increased from $0.44 \mathrm{mg} / \mathrm{kg}$ to $5.08 \mathrm{mg} / \mathrm{kg}$. Oil spillage, effluent discharge, oil exploration wastes and automobile activities, may account for the highest value obtained in Ahoada West $(5.08 \mathrm{mg} / \mathrm{kg})$. The lowest value observed in Eleme $(0.44 \mathrm{mg} / \mathrm{kg})$, may be as a result of the fact that greater proportion of nickel may have been removed during refining, and also the effluents released from NNPC refinery and Eleme Petrochemical industry may have undergone adequate treatment that would have removed high amount of nickel. It was observed (Table 2 and Figure 8), that the mean levels of nickel for all the investigated sites in Rivers $(0.92-5.08 \mathrm{mg} / \mathrm{kg})$ were higher than the control site $(0.89 \mathrm{mg} / \mathrm{kg})$, except Eleme $(0.44 \mathrm{mg} / \mathrm{kg})$ which was lower than the control. However, all the areas examined in Rivers $(0.44-5.08 \mathrm{mg} / \mathrm{kg}$ ) had average nickel values appreciably below DPR standard (35 mg/kg) as shown in Table 2, Table 3 and Figure 8. From these results, the levels of nickel detected in soils from Rivers State were very low; therefore, the soils can guarantee food security in terms of intensive crop production.

The State means for the parameters determined in the soils of the investigated areas in Rivers State are shown in Table 3 and Figure 9.

Table 3 and Figure 9 indicated that the State average $\mathrm{pH}$ value for Rivers (5.38) was far below the control value (6.04) but was slightly below the lower limit (5.50) of DPR standard (5.50 - 5.60), denoting high impact of oil exploration and processing operations in the assessed areas. According to Nkwocha and Duru crude oil makes soil acidic; in other words reduces the $\mathrm{pH}$ of the soil [12]. The strong acidic $\mathrm{pH}$ level could lead to increase availability of micronutrients than macronutrients, reduction in microbial population, and as well favours plant uptake of heavy metals, thereby resulting to toxicity problems. This result (5.38) is at variance with the findings of Udosen et al. who observed a higher $\mathrm{pH}$ value of 5.60 for the bioamendment of petroleum contamination soil [13]. The ANOVA result revealed that there exist no significant difference $(\mathrm{p}=0.413)$ between the soil $\mathrm{pH}$ of the examined areas and the control area (Table 3). This 


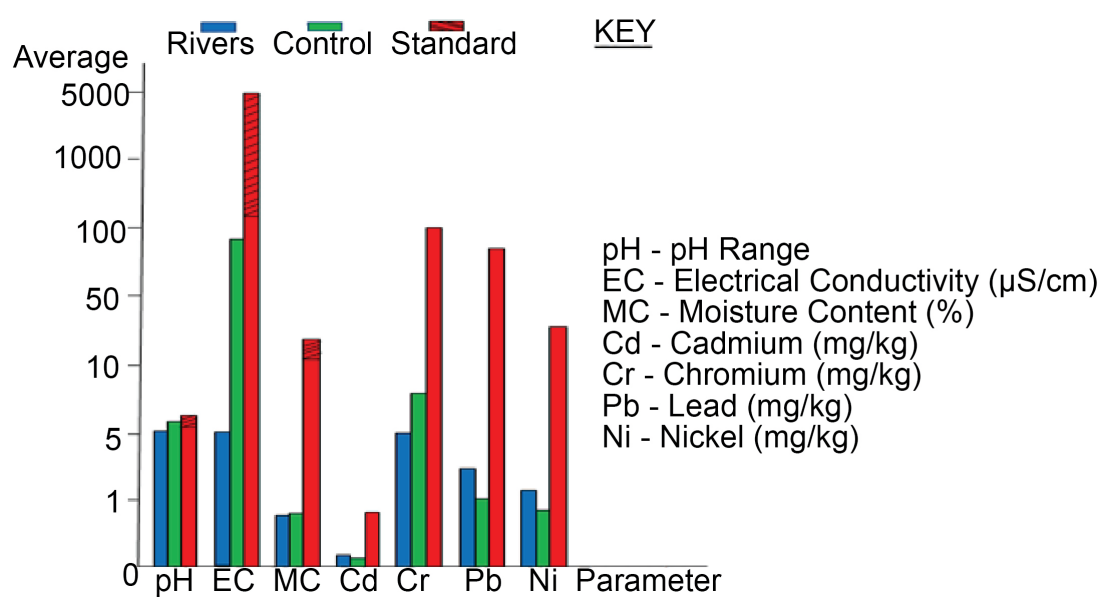

Figure 9. Graphical representation of the State averages for the various parameters.

may be ascribed to their similarity in soil properties.

In Table 3 and Figure 9, the State average electrical conductivity level for Rivers $(5.02 \mu \mathrm{S} / \mathrm{cm})$ was appreciably below the control level $(92.00 \mu \mathrm{S} / \mathrm{cm})$ and DPR regulatory limit $(300-5,000 \mu \mathrm{S} / \mathrm{cm})$. This signified that crude oil exploitation, including sabotage and other handling activities, adversely affected the soil electrical conductivities of these areas, which may result to poor agricultural productivity. The observed value for this study $(5.02 \mu \mathrm{S} / \mathrm{cm})$ is not in agreement with the findings of Ikwa et al. who obtained a higher value $(45.20 \mu \mathrm{S} / \mathrm{cm})$ for soil ecosystem variables affected by oil spills in Etche, Rivers State [14]. ANOVA result (Table 3 ) indicated that the degree of variation of soil electrical conductivities of the studied areas and the control area was insignificant ( $p=0.225)$. This may be related to their similarity in soil composition.

In addition, Table 3 and Figure 9, depicted that the State average moisture content level of soils from Rivers $(0.76 \%)$ was slightly below the control level $(0.80 \%)$, but significantly below DPR limit (13\% - 26\%). This may be due to frequent natural resource extraction coupled with so many oil related industries and facilities in the State. These activities can expose the soil to potentially serious risks, thereby reducing the water holding capacity. The result obtained for this study $(0.76 \%)$ was lower than $23.50 \%$ reported by Akubugwo et al. for studies on the impact of crude oil exploration on soil quality and crops grown in Kpean community, Khana Rivers State [15]. ANOVA result (Table 3) showed that there was no significant difference $(p=0.834)$ between the measured soil moisture contents of the assessed areas and the control area. This may be attributed to the similarity of the parent materials from which their soils were formed.

Table 3 and Figure 9, further indicated that the State average cadmium content of soils studied in Rivers $(0.17 \mathrm{mg} / \mathrm{kg})$ was above the control value $(0.09$ $\mathrm{mg} / \mathrm{kg})$ but significantly below the DPR recommended value $(0.80 \mathrm{mg} / \mathrm{kg})$. Generally, the test soils from Rivers were not polluted in terms of cadmium, implying increase in soil fertility, agricultural potentials and other farm related activi- 
ties and practices. This result $(0.17 \mathrm{mg} / \mathrm{kg})$ is consistent with similar studies conducted by Oriji and Zakka who obtained a mean cadmium level of $<0.2$ $\mathrm{mg} / \mathrm{kg}$, for the physicochemical analysis of a typical crude oil spilled site in Rivers State [16]. From Table 3, the ANOVA result showed that the difference in cadmium concentrations of the test soils and the control soils was statistically insignificant $(\mathrm{p}=0.517$ ). This may be due to their similarity in the composition of the parent soil material.

More so, the State mean chromium value for Rivers $(5.08 \mathrm{mg} / \mathrm{kg}$ ) was predominantly lower than the control $(8.72 \mathrm{mg} / \mathrm{kg})$ and the set standard of DPR (100 $\mathrm{mg} / \mathrm{kg}$ ), as illustrated in Table 3 and Figure 9. This low value observed, provided evidence of unpolluted soils, which will eventually lead to the enrichment of the soil with essential nutrients for efficient crop production. However, the recorded value $(5.08 \mathrm{mg} / \mathrm{kg})$ was significantly higher than the value $(0.34 \mathrm{mg} / \mathrm{kg})$ obtained by Onojake and Okonkwo for trace metals associated with oil spillage in Rivers State [17]. Table 3 further indicated that there was significant difference $(p=0.002)$ between chromium concentrations in the surveyed soils and background soil. This may be due to the effect of oil production and processing operations in the studied locations.

In Table 3 and Figure 9, the State mean level of lead for Rivers $(3.23 \mathrm{mg} / \mathrm{kg}$ ) was above the control site $(1.04 \mathrm{mg} / \mathrm{kg})$ but considerably below $85 \mathrm{mg} / \mathrm{kg}$, the DPR permissible limit. The low concentrations found in these sites denote the potential for improved soil nutrient level. The mean level of lead $(3.23 \mathrm{mg} / \mathrm{kg})$ determined for this present study was greater than $1.20 \mathrm{mg} / \mathrm{kg}$ obtained from previous study by Oriji and Zakka for physicochemical analysis of crude oil spill site in Rivers State [16]. ANOVA result showed that there was no significant degree of variation $(\mathrm{p}=0.538)$ between the lead concentrations in the investigated areas and the control area (Table 3 ). This may be attributed to the composition of the parent material.

Similarly, the assessed soils from Rivers showed a State average nickel concentration of $1.74 \mathrm{mg} / \mathrm{kg}$, which exceeded the control area $(0.89 \mathrm{mg} / \mathrm{kg})$ but was below DPR limit ( $35 \mathrm{mg} / \mathrm{kg}$ ), as indicated in Table 3 and Figure 9. The concentrations of nickel recorded in these areas are insignificant, indicating favourable agricultural output. The result obtained in this assessment $(1.74 \mathrm{mg} / \mathrm{kg})$, is however lower than $(3.14 \mathrm{mg} / \mathrm{kg})$ reported by Onojake and Okonkwo for trace metals associated with oil spillage in Rivers State [17]. Table 3 also revealed that the difference in the nickel contents of soils from the examined soils and the control soil was statistically insignificant $(\mathrm{p}=0.206)$. This may be related to the nature of the parent soil materials.

Generally, the results showed a very low concentrations of all the heavy metals analyzed, compared to DPR limit (Table 3 and Figure 9). The order of abundance of the heavy metals was $\mathrm{Cr}>\mathrm{Pb}>\mathrm{Ni}>\mathrm{Cd}$.

\section{Conclusion}

The test result obtained from the soil analysis of the oil bearing areas in Rivers 
State shows that the soils were acidic and contained low amount of organic matter. Nearly all the physicochemical properties examined were altered by oil pollution since most of the values obtained were far below the recommended DPR Standard. This in turn implies low agricultural productivity and reduced source of livelihood in the affected areas. However, the heavy metals status of the soils were observed to be very low and also below DPR permissible limits. Their effect on soil quality would therefore be insignificant. ANOVA results showed that there was significant difference $(\mathrm{p}<0.05)$ between chromium concentration of the studied soils and the control soils. It can be concluded that the assessed areas in Rivers State, were not yet adversely polluted in terms of oil exploitation and exploration activities. Based on of these findings, periodic monitoring of the study areas is highly recommended to prevent the buildup of the contaminants beyond limits of maximum tolerance.

\section{Conflicts of Interest}

The authors declare no conflicts of interest.

\section{References}

[1] Ukpong, I. E. (2009) Physical Environmental Components and Processes. In: Ukpong, I.E., Ed., Perspectives on Environmental Management, Environmental Systems Club Inc., Uyo, 2-51.

[2] Osuji, L.C. and Onojake, C.M. (2006) Field Reconnaissance and Estimation of Petroleum Hydrocarbon and Heavy Metal Contents of Soils Affected by the Ebocha-8 Oil Spillage in Niger Delta, Nigeria. Journal of Environmental Management, 79, 133-139. https://doi.org/10.1016/j.jenvman.2005.06.004

[3] Phil-Eze, P.O. and Okoro, I.C. (2009) Suitable Biodiversity Conservation in the Niger Delta: A Practical Approach to Conservation Site Selection. Biodiversity and Conservation, 18, 1247-1257. https://doi.org/10.1007/s10531-008-9451-Z

[4] Nwuche, C.O. and Ugorji, E.O. (2010) Effect of Co-Existing Plant Species on Soil Microbial Activity under Heavy Metal Stress. International Journal of Environmental Science and Technology, 7, 697-704. https://doi.org/10.1007/BF03326179

[5] Nigeria Conservation Foundation, International Union for conservation of Nature, Commission on Environmental, Economic and Social Policy and Federal Ministry of Environment (2006) Niger Delta Natural Resources Damage Assessment and Restoration Project Scoping Report. May 2006, P. 27.

[6] Onwurah, I.N.E. (1999) Restoring the Crop Sustaining Potential of Crude Oil Polluted Soil by Means of Azotobacter Inoculation. Plant Production Research Journal, 4, 6-16.

[7] DPR (2002) Environmental Guidelines and Standards for the Petroleum Industry in Nigeria (Revised Edition). Department of Petroleum Resources of Nigeria, Ministry of Petroleum and National Resources Abuja, Nigeria, p. 171.

[8] Amnesty International (2009) Nigeria: "Petroleum Pollution and Poverty in the Niger Delta”. Amnesty International Publications, London, p. 10.

[9] Rivers State City Population (2015) Nigeria-Population Statistics and Location in Maps and Charts. Administrative Division, Rivers State.

[10] Osibanjo, O.A., Kakulu, S.E. and Ajayi, S.O. (1984) Atomic Absorption Spectrophoto- 
metric Determination of Trace Metals in Nigerian Petroleum Using a Mixed-Solvent System. Analyst, 109, 127-129. https://doi.org/10.1039/an9840900127

[11] Masters, G.M. (1991) Introduction to Environmental Engineering and Science. Prentice Hall, Hoboken, 141-145.

[12] Nkwocha, E.E. and Duru, P.O. (2010) Micro-Analytical Study on the Effect of Oil Pollution on Local Plant Species and Food Crops, Research Article. Advances in Bioresearch, 1, 189-198.

[13] Udosen, E.D., Essien, J.P. and Ubom, R.M. (2001) Bioamendment of Petroleum Contaminated Soil: Effect on Oil Content, Heavy Metals and $\mathrm{pH}$ of Tropical Soil. Journal of Environmental Science, 13, 92-98.

[14] Ikwa, L.O., Mmecha, M.I., Umoh, J.D., Nwakamma, H.A. and Nnanyere, O.A. (2015) Investigation of Soil Ecosystem Variables Affected by Oil Spill in Odagwa Etche Rivers State, Nigeria. Journal of Biopesticides and Agriculture, 1, 45-60.

[15] Akubugwo, E.I., Elebe, E.U. and Osuocha, K.U. (2015) Studies on the Impact of Crude Oil Exploration on Soil Quality and Crops Grown in Kpean Community in Khana L.G.A. of Rivers State, Nigeria. International Research Journal of Biochemistry and Biotechnology, 3, 44-50.

[16] Oriji, A.B. and Zakka, S.B. (2014) Physico-Chemical Analysis of a Typical Crude Oil Spilled Site in the Niger Delta of Nigeria. RIJSTR, 5, 511-516.

[17] Onojake, M.C. and Okonkwo, V.I. (2011) Trace Metals Associated with Oil Spillage: A Case Study. Journal of Chemical and Pharmaceutical Research, 3, 742-751. 